\title{
MODIFIKASI MESIN REELING SUTERA MELALUI PENAMBAHAN SISTEM SIRKULASI AIR PANAS OTOMATIS DAN SISTEM PENGEREMAN HASPEL
}

\section{MODIFICATION OF SILK REELING MACHINE THROUGH ADDITION OF AUTOMATIC HOT WATER CIRCULATION AND HASPEL BRAKE SYSTEM}

\author{
Sudiyanto, Mulia Hendra, Doni Sugiyana \\ Balai Besar Tekstil, Jalan Jenderal Ahmad Yani No. 390 Bandung \\ E-mail: texirdti@bdg.centrin.net.id
}

Tanggal diterima: 24 Juli 2014, direvisi: 2 September 2014, disetujui terbit: 24 Oktober 2014

\begin{abstract}
ABSTRAK
Studi ini telah dilakukan dengan mendesain sistem sirkulasi air panas otomatis dan rem haspel sebagai modifikasi pada mesin reeling sutera dengan tujuan untuk konservasi energi melalui peningkatan efisiensi proses. Pada mesin reeling konvensional dapat terjadi inefisiensi pada sistem penyediaan air panas manual yang menyebabkan pelepasan energi panas dan temperatur air yang tidak konstan, serta mekanisme penyambungan benang putus yang dapat mengurangi waktu operasional produktif dan meningkatkan biaya produksi. Metode desain dalam studi ini adalah modifikasi mesin reeling sutera konvensional melalui penambahan sistem sirkulasi air panas otomatis dan sistem pengereman haspel. Berdasarkan uji coba melalui pengoperasian mesin reeling secara kontinyu selama 20 hari, kedua sistem yang dirancang dapat beroperasi dengan baik. Hasil perhitungan analisis ekonomi berdasarkan waktu operasional selama 25 hari memperlihatkan bahwa mesin reeling yang telah dimodifikasi memerlukan biaya produksi benang lebih rendah dan pencapaian waktu break even point yang lebih cepat dibandingkan dengan mesin reeling konvensional. Aplikasi mesin reeling sutera yang telah dimodifikasi ini membutuhkan biaya investasi lebih tinggi, namun demikian produksi benang jauh akan lebih efisien sehingga biaya produksi dalam jangka panjang menjadi lebih rendah dibandingkan dengan mesin reeling konvensional.
\end{abstract}

Kata kunci: efisiensi, reeling, rem haspel, sirkulasi air panas, sutera.

\section{ABSTRACT}

This study has been carried out by designing automatic hot water circulation and haspel brake system as a modification in silk reeling machine, in order to conserve energy through improvement of process efficiency. In the conventional reeling machine, inefficiency could be occurred due to manual hot water supply system which cause release of heat energy and inconstant water temperature, and break yarn joint mechanism which able to reduce productive operational time and increase production cost. Method of design in this study was a modification of conventional silk reeling machine through addition of automatic hot water circulation system and haspel brake system. Based on trial test through 20-days continual operation of reeling machine, both designed systems show good operational performance. Economic analysis calculation based on operational time of 25 days shows that the modified reeling machine requires lower cost production of yarn and faster breakeven point period than that of conventional reeling machine. Application of the modified silk reeling machine needs higher investment cost, however production of yarn will much more efficient, therefore cost production for long term period will be lower than conventional reeling machine.

Keywords: efficiency, haspel brake, hot water circullation, reeling, silk.

\section{PENDAHULUAN}

Industri persuteraan khususnya produksi benang sutera alam merupakan salah satu subsektor agroindustri yang sangat potensial untuk dikembangkan, karena memiliki berbagai keunggulan diantaranya: ketersediaan bahan baku yang berasal dari sumber daya alam lokal, menghasilkan produk komoditi ekspor yang berpotensi meningkatkan devisa, menyerap tenaga kerja yang cukup banyak, dan memiliki keterkaitan yang erat dengan sektor dan sub sektor lainnya. ${ }^{1}$ Namun demikian, potensi pengembangan usaha pemintalan serat sutera alam sangat dipengaruhi oleh beberapa faktor antara lain: ketersediaan bahan baku kokon, jenis peralatan dan mesin pemintalan dan sumber daya manusia yang terampil serta permodalan. ${ }^{\mathbf{1 , 2}}$ Mengingat peralatan/permesinan menjadi salah satu faktor penting pengembangan industri sutera, Balai Besar Tekstil telah berhasil mengembangkan prototip mesin 
pengolah sutera berupa mesin reeling yang berfungsi untuk memintal serat filamen dari kokon sutera alam. ${ }^{2,3}$

Selama proses pemintalan serat sutera menggunakan mesin reeling, kokon direndam di dalam air panas dengan temperatur tertentu yang bertujuan untuk melunakkan serisin yang menempel pada filamen sutera (fibroin). Serisin yang lunak memungkinkan filamen sutera yang menempel satu sama lain menjadi mudah ditarik/terurai. ${ }^{4,5}$ Berdasarkan kajian referensi, studi peningkatan efisiensi pada proses mesin reeling sutera merupakan suatu topik yang tengah intensif dilakukan. ${ }^{6,7,8}$ Demikian pula kajian konservasi energi menjadi topik yang sangat menarik dieksplorasi pada mesin reeling sutera. ${ }^{9,10,11}$ Hasil pengamatan Balai Besar Tekstil terhadap proses pemintalan filamen serat sutera yang menggunakan mesin reeling dalam beberapa tahun terakhir ini di Indonesia khususnya di beberapa sentra industri pengolahan sutera alam, menunjukkan adanya beberapa hal yang perlu disempurnakan. Penyempurnaan yang perlu dilakukan adalah terkait dengan inefisiensi dalam beberapa aspek operasional mesin diantaranya: i) penggantian air selama proses produksi dilakukan secara manual menyebabkan temperatur air tidak dapat diketahui secara tepat dan relatif tidak konstan; ii) penyambungan benang pada saat putus dari penggulung (haspel), dilakukan de-ngan mematikan mesin terlebih dahulu sehingga mengurangi jam produksi efektif.

Sehubungan dengan beberapa permasalahan di lapangan yang disebutkan di atas, maka kondisi ideal yang diharapkan dalam pengoperasian mesin reeling terletak pada aspek: temperatur air dalam bak reeling yang konstan dan terukur; dan kontinuitas proses pengoperasian mesin tanpa proses mematikan mesin apabila terjadi putus benang. Dalam studi ini dilakukan modifikasi desain mesin reeling dengan tujuan mengatasi permasalahan tersebut di atas sehingga dapat meningkatkan efisiensi proses produksi mesin reeling sutera. Untuk mencapai tujuan tersebut, pada studi ini dilakukan pemasangan sistem sirkulasi air panas otomatis serta pemasangan rem penggulung (haspel) ketika terjadi benang putus pada saat proses pemintalan. Melalui riset ini diharapkan akan terwujud proses pengolahan sutera yang efektif, efisien dan dapat diterapkan pada IKM persuteraan alam.

\section{METODE}

Kegiatan modifikasi mesin dilakukan di laboratorium pengembangan Balai Besar Tekstil, Bandung. Sistem sirkulasi air panas otomatis dibuat de-ngan menggunakan prinsip sistem loop tertutup dan sistem resirkulasi. Komponen yang digunakan dalam sistem sirkulasi air panas otomatis adalah: perangkat kontrol temperatur dan ketinggian air, tangki air panas, pompa air, elemen pemanas, termokopel, sensor ketinggian air, katup elektrik, katup kaki, saringan air dan selang tahan panas. Spesifikasi dari setiap komponen yang dipergunakan dalam penelitian modifikasi ini adalah sebagai berikut:

1. Perangkat kontrol temperatur air

Peralatan kontrol elektronik menggunakan micro-controller sebagai penerjemah sinyal/ informasi dari sensor temperatur (termokopel) electric impulse, lalu mengirimkan perintah ke actuator yaitu pemanas listrik (heater) dan katup elektrik sesuai kebutuhan.

2. Perangkat kontrol ketinggian air

Peralatan elektronis dengan microcontroller sebagai penerjemah sinyal/informasi dari sensor (probe) lalu mengirimkan perintah ke actuator yaitu pompa air.

3. Tangki air panas

Tangki pemanas air terbuat dari bahan aluminium dengan diameter $50 \mathrm{~cm}$ dan tinggi $45 \mathrm{~cm}$, memiliki volume \pm 60 liter. Tangki dilengkapi dengan penyaring untuk menyaring air yang dialirkan dari bak perendam kokon sebelum memasuki tangki air panas.

4. Pompa air

Pompa untuk mengalirkan air dari tangki air panas ke bak perendam kokon menggunakan pompa oli mobil yang digerakkan oleh dinamo yang terhubung ke motor listrik.

5. Elemen pemanas

Elemen pemanas memiliki daya 900 watt dengan tujuan mempersingkat waktu untuk memanaskan air. Elemen pemanas dipasang pada tangki air panas.

6. Termokopel

Termokopel merupakan sensor temperatur yang berfungsi menangkap informasi temperatur objek yang ditentukan lalu mengirimkan sinyal ke kontroler temperatur. ${ }^{12,13}$ Sensor temperatur yang digunakan dipasang pada 2 titik yaitu: (i) Pada tangki air panas untuk mendeteksi temperatur air panas, probe sensor berbentuk tombol. (ii) Pada bak perendam kokon untuk mendeteksi temperatur air perendam kokon, probe sensor berbentuk batang silinder.

7. Sensor ketinggian air

Sensor ini untuk mendeteksi posisi ketinggian air pada bak perendam lalu mengirimkan sinyal ke perangkat kontrol ketinggian air, yang selanjutnya mengirim perintah pada pompa untuk menyala atau mati.

8. Katup elektrik

Katup elektrik mengatur pembukaan (membuka dan menutup) secara otomatis, dengan mekanisme apabila temperatur air di dalam bak perendam kokon lebih rendah dari 
Modifikasi Mesin Reeling Sutera Melalui Penambahan Sistem Sirkulasi Air Panas Otomatis dan Sistem Pengereman Haspel

(Sudiyanto, dkk)

temperatur acuan maka katup akan membuka sehingga air akan mengalir menuju tangki air panas, dan sebaliknya.

9. Katup kaki

Katup kaki dipasang pada ujung pipa yang terendam dalam tangki air panas dan berfungsi untuk menjaga tekanan pompa sekaligus menyaring air yang dihisap oleh pompa.

10. Saringan air

Saringan air ditempatkan pada ujung pipa yang masuk ke tangki pemanas air. Saringan air terbuat dari bahan akrilik terdiri dari 3 lapisan/lembaran dengan ketebalan tiap lapisan 3 $\mathrm{mm}$,

11. Selang tahan panas

Selang digunakan untuk pengganti pipa sebagai media untuk mengalirkan air dalam sistem sirkulasi. Selang dapat bertahan untuk mengalirkan air sampai dengan temperatur mendekati $100^{\circ} \mathrm{C}$.

Sistem pengereman haspel dirancang dengan sistem knock-down agar dapat dengan mudah dibongkar pasang pada mesin reeling. Komponen yang digunakan dalam sistem pengereman haspel adalah: handle (pegangan), pengungkit haspel, rol putar dan per penekan. Spesifikasi kerja dari setiap komponen dalam desain sistem rem haspel adalah sebagai berikut:

1. Pegangan (handle)

Handle merupakan bagian perpanjangan tuas pengungkit yang menjadi pegangan operator untuk mengubah posisi pengungkit rem.

2. Pengungkit rem

Pengungkit rem merupakan bagian yang langsung bersentuhan dengan haspel dan alat ini bekerja untuk menahan laju perputaran haspel.

3. Rol putar

Rol putar merupakan bagian yang menghubungkan antara ujung tuas pengungkit dengan pengungkit rem. Pergerakan tuas pengungkit menyebabkan rol putar akan berputar searah jarum jam dan mengangkat pengungkit rem

4. Rangka dengan per penekan

Rangka dilengkapi per penekan bekerja melindungi tuas pengungkit sekaligus menjadi lokasi titik putar tuas. Per penekan berfungsi untuk menahan batang pengungkit pada posisi rem dan untuk mengembalikan seperti semula.

Perhitungan nilai break even point (BEP) dan return of investment (ROI) untuk menganalisis investasi modifikasi mesin reeling dilakukan dengan mengikuti persamaan (1) dan (2). ${ }^{14}$

$B E P=\frac{F C}{S P-V C}$

\author{
Dimana, \\ BEP : Break Even Point \\ FC : Fixed Cost/biaya tetap (Rp) \\ $\mathrm{SP} \quad$ : Selling Price/harga jual $(\mathrm{Rp} / \mathrm{kg})$ \\ $\mathrm{VC} \quad$ : Variable Cost/biaya variabel $(\mathrm{Rp} / \mathrm{kg})$ \\ $R O I=\frac{\text { Profit }}{\text { Investasi }} \times 100 \%$

\section{HASIL DAN PEMBAHASAN}

\section{Sistem sirkulasi air panas otomatis}

Hasil modifikasi sistem sirkulasi air panas otomatis dan mekanisme kerjanya ditunjukkan pada Gambar 1. Sistem sirkulasi air panas otomatis bekerja melalui kombinasi dari pengaturan kerja secara bersama-sama beberapa komponen utama sistem, yaitu: pemanas, pompa air dan katup buang. Komponen pemanas akan bekerja apabila temperatur air di dalam tangki air panas berdasarkan informasi dari sensor berada di bawah temperatur acuan/set value (SV). Komponen pompa air bekerja saat ketinggian air pada bak perendam berada di bawah batas acuan terendah. Komponen katup buang bekerja apabila temperatur air perendam berada di bawah SV.

Sistem sirkulasi air panas otomatis bekerja dengan baik melalui beberapa proses yang berjalan simultan. Kondisi awal diasumsikan berada pada kondisi di mana temperatur acuan sama dengan temperatur aktual/processing value (PV), ketinggian air bak perendam normal dan katup buang tertutup (Gambar 1-a). Ketika PV lebih rendah dari SV, maka temperatur air dalam bak perendam turun di bawah nilai acuan akibat adanya proses perpindahan panas baik dari air ke udara maupun ke bak. Jika terjadi kondisi seperti ini maka pengatur temperatur akan memerintahkan katup buang untuk membuka sehingga air dalam bak perendam mengalir ke tangki air panas melalui katup buang tersebut. Sistem pada kondisi ini ditampilkan sesuai ilustrasi pada Gambar 1-b.

Pada tahap selanjutnya, permukaan air akan turun hingga berada di bawah batas acuan sehingga sensor ketinggian air bekerja memerintahkan pompa untuk bekerja mengalirkan air dari tangki air panas ke bak perendam kokon sampai ketinggian air mencapai batas acuan. Selama proses penambahan air, sensor temperatur terus bekerja memantau temperatur air perendam kokon hingga mencapai keadaan PV sama dengan SV. Sistem pada kondisi ini ditampilkan sesuai ilustrasi pada Gambar 1-c. Ketika kondisi PV telah sama dengan $\mathrm{SV}$, pengatur temperatur akan memerintahkan katup buang untuk menutup sehingga air berhenti mengalir. Pada kondisi ini pompa terus bekerja sampai ketinggian air di dalam bak perendam mencapai batas acuan. Siklus proses di atas akan 
terus berulang sesuai dengan kondisi yang terjadi. Kondisi kerja sistem kontrol sirkulasi air panas otomatis yang merupakan fungsi dari temperatur aktual (PV) dan temperatur acuan (SV) secara keseluruhan digambarkan pada Tabel 1 .

(a)

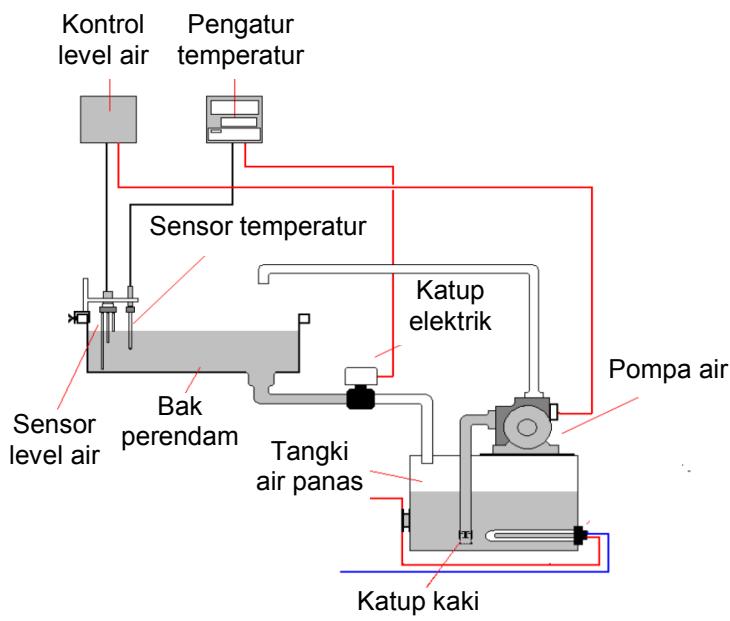

(b)

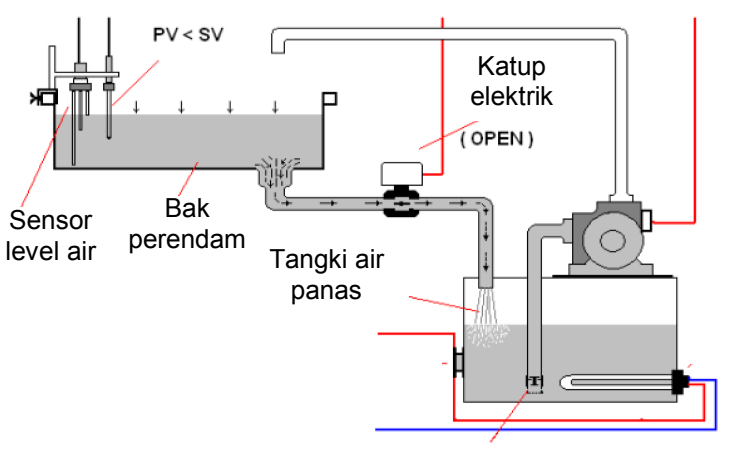

(c)

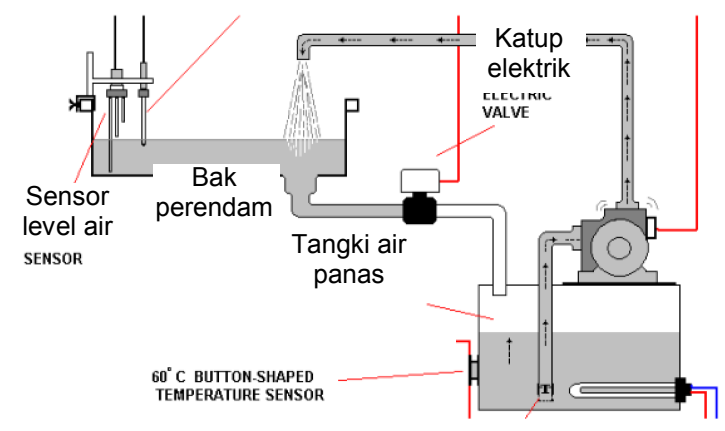

Gambar 1. Skema rancangan sistem sirkulasi air panas otomatis : a) Kondisi awal sistem belum bekerja, b) Sistem bekerja ketika temperatur air dalam bak perendam turun di bawah nilai acuan, c) Sistem bekerja ketika permukaan air dalam bak perendam turun di bawah batas acuan
Tabel 1. Kondisi kerja sistem kontrol sirkulasi air panas otomatis

\begin{tabular}{cccc}
\hline Temperatur & Level air & $\begin{array}{c}\text { Pom- } \\
\text { pa }\end{array}$ & Katup \\
\hline $\mathrm{PV}=\mathrm{SV}$ & Normal & Off & Off \\
$\mathrm{PV}<\mathrm{SV}$ & Normal & Off & On \\
$\mathrm{PV}<\mathrm{SV}$ & Rendah & On & On \\
$\mathrm{PV}=\mathrm{SV}$ & Rendah & On & Off \\
$\mathrm{PV}=\mathrm{SV}$ & Normal & Off & Off \\
\hline
\end{tabular}

\section{Sistem pengereman haspel}

Modifikasi sistem dibuat dengan cara mekanisme pengereman haspel untuk menghentikan putaran jika terjadi benang putus selama proses penggulungan filamen. Hasil desain sistem pengereman haspel ditunjukkan pada Gambar 2. Prinsip kerja alat pengereman haspel dirancang dengan mengadopsi mekanisme pengungkit/tuas, seperti ditunjukkan pada Gambar 3.
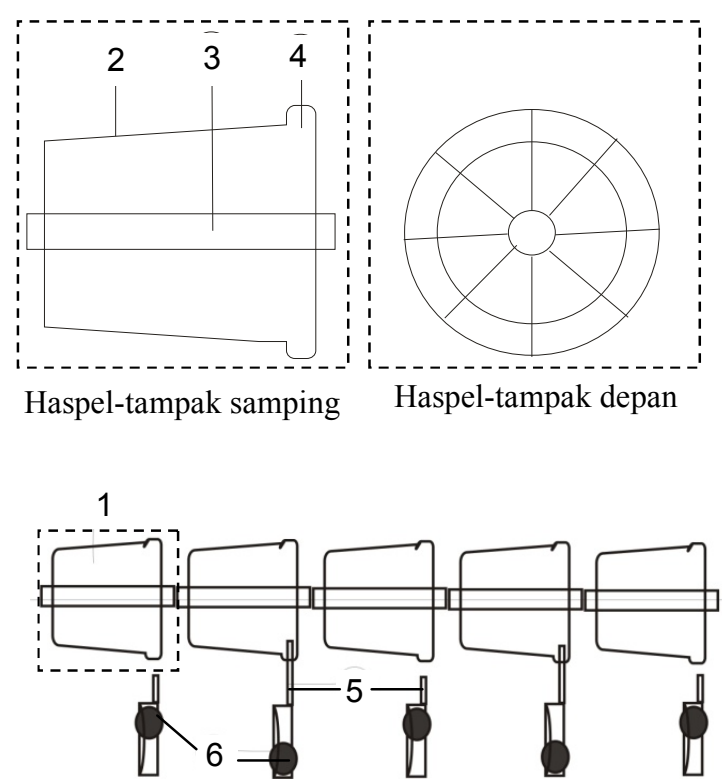

Gambar 2. Haspel dan posisi rem terhadap haspel (Keterangan: 1.Haspel; 2.Permukaan gulungan benang pada haspel; 3.Bos Haspel; 4.Kuping Haspel; 5. Pengungkit rem; 6.Handle rem)

Sistem pengereman haspel bekerja melalui mekanisme sederhana: handle (1) ditekan ke arah bawah pada saat terjadi putus benang, selanjutnya tuas pengungkit berputar pada titik putar (2) sehingga rol putar (4) pada ujung tuas pengungkit yang menghubungkan tuas dengan pengungkit akan berputar searah jarum jam dan pengungkit (3) akan terangkat, akibatnya akan menahan putaran haspel seketika.

Satu unit rem haspel dirancang untuk satu haspel, sehingga jika terjadi benang putus pada 
salah satu haspel maka cukup hanya haspel tersebut saja yang dihentikan sedangkan haspel yang tidak mengalami benang putus dapat terus berputar sebagaimana mestinya. Jadi selama proses penggulungan filamen, tidak perlu lagi mematikan motor jika terjadi benang putus pada salah satu atau beberapa haspel.

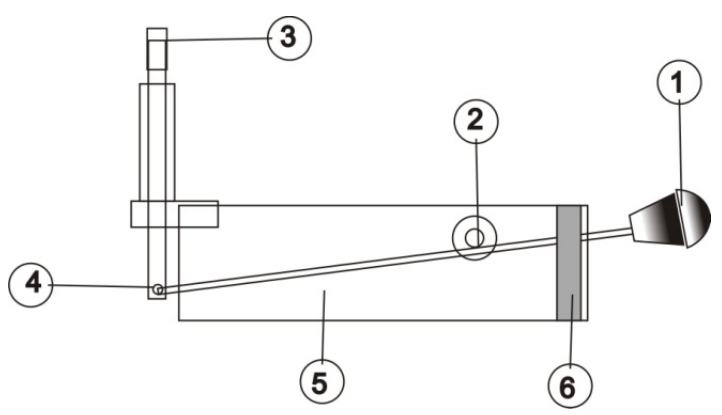

Gambar 3. Diagram pengereman haspel (Keterangan: 1.Handle/pegangan; 2.Titik putar tuas; 3.Pengungkit rem; 4.Rol putar; 5.Rangka; 6.Per penekan).

\section{Uji coba sistem}

Uji coba dilakukan pada mesin reeling 4 delivery yang telah mengalami modifikasi penambahan rem haspel untuk masing-masing haspel serta peralatan kontrol sistem sirkulasi air panas otomatis. Uji coba operasional mesin tanpa bahan baku dilakukan untuk mengevaluasi performa beberapa komponen tambahan dalam modifikasi. Proses uji coba dilakukan selama 4 minggu dan dalam 1 minggu uji coba dilakukan selama 5 hari dengan proses 8 jam non-stop setiap harinya. Pengamatan dilakukan setiap hari dan dibuat resume pada hari ke-5 sebagai hasil pengamatan mingguan. Proses uji coba mesin dengan bahan baku kokon dilakukan selama 2 (dua) hari yaitu pada dua hari terakhir, bertujuan untuk mengetahui kinerja saringan air dan kontinuitas pro-ses reeling. Uji coba dengan bahan dilakukan dengan menggunakan kokon sutera sebanyak $3 \mathrm{~kg}$. Hasil pengamatan selama proses uji coba diperlihatkan pada Tabel 2.

Uji coba kontrol sistem sirkulasi air panas otomatis dilakukan dengan mengecek fungsi setiap komponen sistem sirkulasi air panas otomatis. Selain fungsi setiap komponen, pengamatan juga dilakukan terhadap mekanisme kerja sistem sirkulasi air panas pada saat seluruh komponen sistem bekerja bersamaan. Hasil pengamatan terhadap fungsi dari setiap komponen sistem sirkulasi air panas sebagaimana ditampilkan pada Tabel 2, menunjukkan bahwa setiap komponen memperlihatkan fungsi yang baik pada ujicoba selama 4 minggu.
Tabel 2.Hasil uji coba performa mesin reeling sutera yang telah dimodifikasi

\begin{tabular}{lcccc}
\hline \multirow{2}{*}{ Komponen } & \multicolumn{5}{c}{ Pengamatan minggu ke: } \\
\cline { 2 - 5 } & $\mathbf{1}$ & $\mathbf{2}$ & $\mathbf{3}$ & $\mathbf{4}$ \\
\hline Pompa air & $\sqrt{ }$ & $\sqrt{ }$ & $\sqrt{ }$ & $\sqrt{ }$ \\
Pemanas & $\sqrt{ }$ & $\sqrt{ }$ & $\sqrt{ }$ & $\sqrt{ }$ \\
Saringan air & & & & $\sqrt{ }$ \\
Katup-katup & $\sqrt{ }$ & $\sqrt{ }$ & $\sqrt{ }$ & $\sqrt{ }$ \\
Sensor temperatur & $\sqrt{ }$ & $\sqrt{ }$ & $\sqrt{ }$ & $\sqrt{ }$ \\
Sensor level air & $\sqrt{ }$ & $\sqrt{ }$ & $\sqrt{ }$ & $\sqrt{ }$ \\
Panel kontrol & $\sqrt{ }$ & $\sqrt{ }$ & $\sqrt{ }$ & $\sqrt{ }$ \\
Selang sirkulasi & $\mathrm{o}$ & $\mathrm{o}$ & $\mathrm{o}$ & $\mathrm{o}$ \\
Tangki air panas & $\mathrm{o}$ & $\mathrm{o}$ & $\mathrm{o}$ & $\mathrm{o}$ \\
Rem haspel & $\sqrt{ }$ & $\sqrt{ }$ & $\sqrt{ }$ & $\sqrt{ }$ \\
Keterangan: & & & & \\
$\sqrt{ }=$ berfungsi dengan baik & & & \\
o $=$ tidak ada kebocoran & & &
\end{tabular}

Pengamatan terhadap mekanisme kerja seluruh komponen sistem bekerja bersamaan juga menunjukkan bahwa temperatur dalam bak reeling selalu stabil. Sepanjang waktu pengamatan, penurunan temperatur air dalam bak reeling secara otomatis diikuti dengan pergantian air dengan air yang telah dipanaskan secara kontinyu dalam tangki air panas. Aplikasi mekanisme sistem ini di lapangan akan memastikan bahwa proses produksi reeling sutera tidak akan mengalami jeda atau pemberhentian sementara.

Pengamatan terhadap kinerja saringan dilakukan dengan memeriksa kondisi visual air pada bak reeling pada proses uji coba mesin dengan bahan baku kokon. Kondisi visual air pada bak reeling sebelum dan sesudah penyaringan ditunjukkan pada Gambar 4. Pada proses operasi mesin reeling seiring dengan proses pemintalan kokon, air akan semakin kotor yang diakibatkan oleh material yang ditinggalkan oleh kokon setelah dipintal menjadi benang. Hal ini dapat mengganggu kualitas proses reeling apabila air yang sudah kotor tidak dibersihkan melalui saringan.
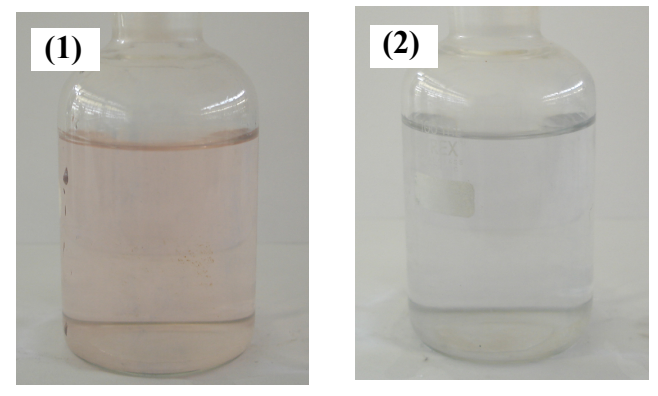

Gambar 4. Kondisi visual air pada bak reeling (Keterangan: 1. Sebelum disaring; 2. Setelah disaring). 
Pengamatan pada mesin reeling hasil modifikasi dilakukan pada saat air dalam kondisi kotor dan mengalami penurunan temperatur sampai di bawah temperatur acuan, air dalam bak reeling mengalir ke dalam tangki pemanas melalui saringan. Setelah permukaan air dalam bak reeling turun di bawah permukaan acuan maka air yang sudah tersaring akan mengalir kembali ke bak reeling. Dari hasil pengamatan visual terlihat bahwa saringan cukup efektif memisahkan material pengotor pada air perendam kokon.

Uji coba mekanisme pengereman haspel dilakukan untuk mengecek fungsi dari masingmasing rem haspel ketika mesin reeling tengah dioperasikan. Setting posisi pengungkit dibuat tegak lurus pada kuping haspel agar tidak mengenai bagian permukaan gulungan benang haspel. Hasil pengamatan sistem pengereman haspel berfungsi dengan baik, dimana ketika terjadi benang putus pada salah satu atau beberapa haspel maka cukup hanya menekan handle rem pada haspel yang men- galami benang putus saja. Haspel yang mengalami pengereman akan berhenti berputar, sedangkan haspel yang tidak mengalami benang putus tetap berjalan secara normal tanpa harus mematikan mesin secara keseluruhan.

Berdasarkan pengamatan di lapangan, proses menyambung benang dari kokon sutera yang terputus mengkonsumsi waktu antara 1-5 menit. Selain itu frekuensi terjadinya putus benang relatif sering pada kondisi kokon yang tidak segar. Pada mesin reeling konvensional, ketika terjadi benang putus saat proses penggulungan haspel maka mesin dimatikan terlebih dahulu untuk menyambung benang yang putus. Hal ini menyebabkan haspel yang tidak mengalami putus benang juga ikut berhenti sehingga mengakibatkan berkurangnya waktu efektif produksi. Berdasarkan pengamatan dari rangkaian uji coba terhadap mesin reeling hasil modifikasi, dapat disimpulkan bahwa kedua sistem dapat berfungsi dengan baik.

Tabel 3. Perbandingan variabel produksi antara mesin reeling A dan B

\begin{tabular}{|c|c|c|c|}
\hline No & Variabel produksi & Mesin A & Mesin B \\
\hline 1 & Harga mesin reeling 4 delivery & Rp. 15.000 .000 & Rp. 20.000 .000 \\
\hline 2 & Usia ekonomi (economic life) & 5 tahun ( 60 bulan) & 5 tahun (60 bulan) \\
\hline 3 & Kapasitas produksi per hari & $0,72 \mathrm{~kg}$ & $1,44 \mathrm{~kg}$ \\
\hline 4 & Kapasitas produksi per bulan & $18 \mathrm{~kg}$ & $36 \mathrm{~kg}$ \\
\hline 5 & Waktu produksi per hari & 8 jam & 8 jam \\
\hline 6 & Durasi mesin berhenti per hari & $4,5 \mathrm{jam}$ & $1 \mathrm{jam}$ \\
\hline 7 & Durasi mesin beroperasi per hari & $3,5 \mathrm{jam}$ & $7 \mathrm{jam}$ \\
\hline 8 & Waktu kerja per bulan & 25 hari & 25 hari \\
\hline 9 & Konsumsi LPG per hari & $1,4 \mathrm{~kg}$ & - \\
\hline 10 & Harga gas LPG tabung $3 \mathrm{~kg}$ & Rp. 19.000,- & - \\
\hline 11 & Konsumsi LPG dalam 25 hari & $\begin{array}{c}36 \mathrm{~kg} \text { (12 tabung isi } 3 \\
\mathrm{~kg} \text { ) }\end{array}$ & - \\
\hline 12 & Daya listrik pompa air & - & 90 watt \\
\hline 13 & Daya listrik pemanas air & - & 900 watt \\
\hline 14 & Total kebutuhan daya listrik & - & 990 watt \\
\hline 15 & Daya listrik (home industry) & - & 1300 watt \\
\hline 16 & Konsumsi listrik per hari & - & $6,93 \mathrm{kWh}$ \\
\hline 17 & Harga listrik per $\mathrm{kWh}$ & - & Rp. 1.090,- \\
\hline 18 & Biaya langganan listrik per bulan & - & Rp. $44.000,-$ \\
\hline 19 & Harga jual benang per $\mathrm{kg}$ & Rp. 450.000,- & Rp. 450.000,- \\
\hline
\end{tabular}


Modifikasi Mesin Reeling Sutera Melalui Penambahan Sistem Sirkulasi Air Panas Otomatis dan Sistem Pengereman Haspel (Sudiyanto, dkk)

Tabel 4. Perbandingan variabel biaya antara mesin reeling A dan B

\begin{tabular}{|c|c|c|c|}
\hline No & Variabel biaya & Mesin A & Mesin B \\
\hline 1 & $\begin{array}{l}\text { Biaya penyusutan } \\
\text { mesin dalam } 5 \text { ta- } \\
\text { hun }\end{array}$ & $\frac{\text { Rp. } 15.000 .000}{5 \times 12 \text { bulan }}=$ Rp. $250.000 /$ bulan & $\frac{\text { Rp. } 20.000 .000}{5 \times 12 \text { bulan }}=$ Rp. $333.333 /$ bulan \\
\hline 2 & $\begin{array}{l}\text { Biaya pemakaian } \\
\text { gas per bulan }\end{array}$ & Rp. $19.000 \times 12=$ Rp. 228.000 & 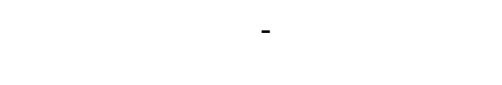 \\
\hline 3 & $\begin{array}{l}\text { Biaya pemakaian } \\
\text { listrik per bulan dan } \\
\text { biaya abodemen } \\
\text { listrik daya } 1300 \\
\text { watt }\end{array}$ & ( & $\begin{array}{l}\text { (Rp. } 7553,7 \times 25 \text { hari })+ \text { Rp. } 44.000= \\
\text { Rp. } 232.842 / \text { bulan }\end{array}$ \\
\hline 4 & $\begin{array}{l}\text { Total biaya opera- } \\
\text { sional di luar opera- } \\
\text { tor per bulan }\end{array}$ & $\begin{array}{l}\text { Rp. } 228.000+\text { Rp. } 250.000= \\
\text { Rp. } 478.000 / \text { bulan }\end{array}$ & $\begin{array}{l}\text { Rp. } 333.333+\text { Rp. } 232.842=\text { Rp. } \\
\text { 566.175/bulan }\end{array}$ \\
\hline 5 & $\begin{array}{l}\text { Biaya produksi per } \\
\mathrm{kg} \text { benang }\end{array}$ & $=\frac{\mathrm{Rp} \cdot 478.000}{18 \mathrm{~kg}}=\mathrm{Rp} \cdot 26 \cdot 555,-\mathrm{kg}$ & $=\frac{\mathrm{Rp} .566 .175}{36 \mathrm{~kg}}=\mathrm{Rp} \cdot 15.727 / \mathrm{kg}$ \\
\hline
\end{tabular}

\section{Analisis biaya}

Analisis biaya ini bertujuan untuk memperbandingkan kelayakan ekonomi antara investasi pada mesin reeling konvensional (mesin A) dengan mesin reeling yang telah dimodifikasi dengan penambahan sistem kontrol sirkulasi air panas otomatis dan sistem pengereman haspel (mesin B). Beberapa aspek yang diperbandingkan adalah biaya produksi per $\mathrm{kg}$ benang, break even point dan return of investment. Variabel biaya yang diasumsikan sebanding dalam pengoperasian kedua jenis mesin, diantaranya: biaya bahan baku, upah tenaga kerja dan sebagainya tidak diperhitungkan dalam analisis ekonomi ini. Faktor biaya yang diperhitungkan hanya variabel yang berpengaruh dalam perbandingan biaya operasional untuk kedua sistem.

Dengan perhitungan pengoperasian mesin reeling sutera selama 30 hari untuk kedua sistem, maka dapat diperbandingkan variabel produksi untuk kedua mesin seperti ditampilkan pada Tabel 3. Perhitungan biaya produksi untuk kedua mesin juga ditampilkan pada Tabel 4 dengan perbandingan perhitungan variabel biaya antara kedua mesin. Berdasarkan perhitungan variabel biaya seperti ditunjukkan pada Tabel 4, maka perbandingan biaya produksi per $\mathrm{kg}$ benang antara mesin $\mathrm{B}$ dan mesin A adalah Rp. 15.727 : Rp. 26.555. Dari hasil perhitungan ini dapat diketahui bahwa mesin reeling sutera dengan mo-difikasi mampu meningkatkan efisiensi dan mengkonservasi kebutuhan energi hingga mampu menekan biaya produksi hingga $59 \%$ dari mesin reeling sutera konvensional.

Nilai break even point (BEP) dan return of investment (ROI) pada investasi mesin A dan B dengan perhitungan mengikuti persamaan (1) dan (2). Seperti halnya pada perhitungan biaya produksi, perhitungan BEP dan ROI dilakukan dengan mengabaikan komponen biaya lainnya baik biaya tetap (sewa tempat, upah tenaga kerja dsb.) maupun biaya variabel (bahan baku, bahan penolong dsb.).
Berdasarkan persamaan (1), mesin A akan mencapai BEP setelah dihasilkan produk sebanyak 40,2 kg, sedangkan pada mesin B, BEP tercapai setelah dihasilkan produk sebanyak 52,1 kg. Dengan memperhitungkan kapasitas produksi maka pencapaian BEP pada mesin A dan B masingmasing akan tercapai setelah 2,2 dan 1,4 bulan. Dengan memperbandingkan kapasitas produksi, harga jual, biaya produksi dan modal investasi untuk mesin A dan B, perhitungan mengikuti persamaan (2) memperoleh nilai ROI masing-masing sebesar $44,8 \%$ dan $69,2 \%$.

Hasil analisis ekonomi ini memperlihatkan bahwa mesin reeling yang telah dimodifikasi dengan penambahan sistem kontrol sirkulasi air panas otomatis dan sistem pengereman haspel membutuhkan biaya produksi lebih rendah, pencapaian BEP lebih cepat dan nilai ROI yang lebih tinggi dibandingkan mesin reeling sutera konvensional. Perlu ditegaskan kembali bahwa nilai-nilai yang muncul dalam analisis ekonomi ini hanya ditujukan dalam konteks perbandingan antara kedua mesin, dan bukan merupakan nilai - nilai perhitungan ekonomi sesungguhnya mengingat adanya parameter untuk variabel-variabel produksi yang diasumsikan sebanding antara kedua mesin yang diperbandingkan.

\section{KESIMPULAN}

Berdasarkan studi modifikasi mesin reeling sutera yang telah dilakukan, dapat disimpulkan bahwa penggunaan sistem kontrol sirkulasi air panas otomatis dapat memangkas kegiatan untuk proses pemanasan dan penggantian air sehingga proses produksi lebih efektif dan efisien. Penggunaan sistem pengereman haspel dapat meningkatkan efisiensi dan efektivitas proses produksi karena pada saat terjadi benang putus tidak perlu mematikan mesin namun cukup dengan menghentikan putaran haspel yang mengalami benang putus 
menggunakan rem haspel kemudian benang dapat disambung kembali. Investasi pada mesin reeling yang telah dimodifikasi mampu menghemat biaya produksi, mempercepat pencapaian BEP dan perolehan nilai ROI yang lebih tinggi dibandingkan dengan mesin reeling konvensional. Penelitian lanjutan kiranya perlu dilakukan lagi untuk mengevaluasi performa mesin yang telah dimodifikasi dengan disertai penggunaan bahan baku, sehingga dapat diperoleh data hasil pengujian kualitas produk mesin reeling.

\section{PUSTAKA}

${ }^{1}$ Atmosoedarjo, H.S., Kartasubrata, J., Kaomini, M., Saleh, W., dan Moerdoko, W., (2000), Sutera Alam Indonesia, Penerbit Yayasan Sarana Wana Jaya, Jakarta.

2 Mulyana, A., (2003), Laporan modifikasi mesin reeling buatan Balai Besar Tekstil dalam rangka meningkatkan kualitas benang sutera alam (filament), Laporan Kegiatan Riset Balai Besar Tekstil.

${ }^{3}$ Natawijaya, D., (2001), Laporan pelatihan pemintalan sutera alam bagi industri kecil pemintalan sutera alam, Laporan Kegiatan Riset Balai Besar Tekstil.

${ }^{4}$ Lakshmipathaiah, B.N., Hariraj, G., Naik, S.V., dan T.H.Somashekar, (2000) "A reeling technology package for producing gradable quality raw silk from cross breed cocoons" Indian Silk, July, 24-29.

${ }^{5}$ Vermaas, J.F. dan Steyn, H.J., (2012), Evaluaton of physical properties of locally produced Gonometa Postica Silk and wool Fabrics, Journal of Family Ecology and Consumer Sciences, Vol. 40, 74-82.
${ }^{6}$ Naik, S.V., Somashekar T.H., dan Takabayashi, C., (2005) Influence of defective cocoons on reeling performance and quality of raw silk, Indian silk, Vol.43, No.12, 20-31.

${ }^{7}$ Naik, S.V., dan Somashekar T.H. (2008), Effect of degree of cocoon drying and cocoon cooking condition on reeling performance and quality of raw silk of Indian bivoltine cocoons, Japan Society of Silk Science and Technology Vol.17, 27-32.

${ }^{8}$ Naik, S.V., Malali, K., Naik, P.Y., Roy, S., dan Somashekar, T.H., (2010), Studies on production of blend silk yarns using man-made filament/natural fibre's yarns during silk reeling and properties of these yarns: Part I, ManMade Textiles in India, August, 302-304.

9 Mande, S., Pai, B.R., dan Kishore, V.V.N., (2000), Study of stoves used in the silk-reeling industry, Biomass and Bioenergy 19, 5-61

${ }^{10}$ Kathari, V.P., Patil, B.G., dan Das, S., (2010), A new energy efficient process with solar water heating system for multiend silk reeling unit, Indian Journal of Fibre \& Textile Research Vol. 35, 277-280.

${ }^{11}$ Kathari, V.P., Patil, B.G., \& Das, S., (2011), An energy efficient re-reeling process for silk reeling industry to reduce deforestation, Indian Journal of Fibre and Textile Research Vol. 36, 96-98.

${ }^{12}$ Cengel, Yunus A. dan Boles, M.A., (1998), Thermodynamics and Engineering Approach, McGraw-Hill, New York.

${ }^{13}$ Cengel, dan Yunus A., (2002), Heat Transfer - A practical approach, Second Edition, McGrawHill, New York.

${ }^{14}$ Giessmann, A., (2012). Coating Substrates and Textiles: Investment Probability Analysis, Springer-Verlag Berlin Heidelberg, 217-236. 